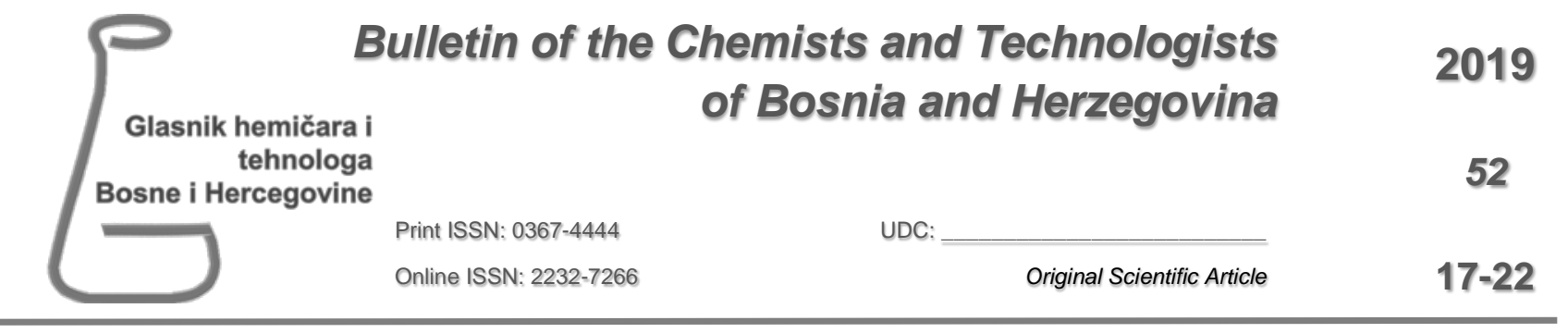

\title{
Experimental and theoretical study of Aspartic acid
}

\author{
Movre Šapić, I. ${ }^{a}$, Vidak, A. ${ }^{a}$, Dananić, V. ${ }^{a}$ \\ ${ }^{a}$ Faculty of Chemical Engineering and Technology, University of Zagreb, Savska cesta 16, 10000 Zagreb, Croatia
}

\section{Article info \\ Received: 26/03/2019 \\ Accepted: 17/06/2019}

\author{
Keywords: \\ Aspartic acid \\ FTIR \\ Raman \\ Zwitterion \\ Quantum chemistry
}

\begin{abstract}
The aim of this research is to detect zwittterionic structure of the aspartic acid and confirm the experimental spectra with quantum chemical calculations. The experimental IR and Raman spectra of aspartic acid powder show no vibrational bands of $\mathrm{OH}$ and $\mathrm{NH}$ stretching in expected spectral region. We assume that zwitterionic structure of aspartic acid is responsible for lowering the frequencies of these vibrations. An extensive experimental and computational research supports this assumption. Our DFT calculation strongly suggests the need for the dielectric environment in order to stabilize the zwitterionic structure of a single molecule. The network of intermolecular hydrogen bonding between aspartic acid molecules provides this dielectric environment. The DFT quantum mechanical calculations corroborate this assumption by optimizing a four-member group of molecules, which also gives an explanation of broad IR spectrum lines.
\end{abstract}

\section{INTRODUCTION}

Aspartic acid is one of the twenty amino acids which together form the basic building blocks of proteins, enzymes and other body tissues. Proteolytic enzymes known as aspartic proteases each possess two aspartic acid residues at the active site. Aspartic acid provides the amino group in the urea cycle and in the biosynthesis of purine and synthesis of pyramidine (Garett and Grisham, 2010). It is a precursor of the pyrimidine nucleotides and, in addition, is a key precursor for the synthesis of asparagine, methionine, lysine, threonine, and isoleucine (Garett and Grisham, 2010). It is known that these amino acids are participating in a variety of biochemical reactions, basic energy transfer and muscle activity and they are used for medical, cosmetic and industrial purposes (Zhu et al., 2011, Patil et al., 2018). It is also found that at higher concentrations aspartic acid affects the lifetime of the initial phase of $\mathrm{CaCO}_{3}$ crystallization, the amorphous calcium carbonate, through the inhibition of crystal nucleation and growth (Tobler et al., 2014). The knowledge of the vibrational spectra of amino acids is very useful for lots of biochemical studies involving enzymes, proteins and their reactions (Navarrete, Hernández and Ramírez, 1994, Kumar, 2016, Numata et al., 2017). Several authors have demonstrated that the most stable structure for a free amino acid molecule is the nonzwitterionic form (NH2-CHR-COOH) (Alam and Ahmad, 2012), but it is possible to find a local minimum for the zwitterionic form (NH3+-CHR-CO2-) and the calculated frequencies were compared to IR and Raman spectra (Navarrete, Hernández and Ramírez, 1994, Freire et al., 2017, Silva et al., 2015). The molecule structure in solid state has been determinate by $\mathrm{x}$-ray diffraction techniques and it occurs in the crystal as a zwitterion (Derissen, Endeman and Peerdeman, 1968). Single molecule has the absolute minimum of energy in the non zwitterionic structure but the zwitterionic structure is stabilized with other amino acid molecules in the solid state or with the solvent molecules in a solution (Navarrete, Hernández and Ramírez, 1994, Paxton and Harper, 2004, Nagy and Noszál, 2000). That property is also observed with smaller amino acids such as alanine and glycine (Ilijima, Tanaka and Onuma, 1991, Alper, Dothe and Coker, 1991, Ilijima and Beaglev, 1991, Gontrani, Mennucci and Tomasi, 2000).

Structure of the aspartic acid molecule in a solution also depends on the $\mathrm{pH}$ value of the solution (Paxton and Harper, 2004, Castro et al., 1995).

Our motivation to further contribute to this well explored subject is twofold. First, we have noticed there are no vibrational bands of $\mathrm{OH}$ and $\mathrm{NH}$ stretching in expected experimental spectral region. One possible explanation, as given in literature (Navarrete, Hernández and Ramírez, 
1994), is in vast number of intermolecular hydrogen bonds. However, to apply this explanation on bands at 2510, 2661 and $2729 \mathrm{~cm}^{-1}$ the required frequency shift would be over $1000 \mathrm{~cm}^{-1}$. The shift of such magnitude ascribed to hydrogen bonding is not commonly found. We argue that alongside hydrogen bonding there are quasi-free proton movements between two oxygen atoms and oxygen and nitrogen atoms. Second, our IR spectra of powder sample persistently showed broad bands, in spite of good spectrometer`s resolution of $1 \mathrm{~cm}^{-1}$.

\section{MATERIALS AND METHODS}

The supplier of $\geq 98 \%$ L-aspartic acid was Sigma-Aldrich. To observe interactions experimentally, powder sample was characterized by attenuated total reflectance Fourier transform infrared spectroscopy (ATR FTIR), with Bruker Vertex 70 instrument. The absorbance data were collected between 400 and $4000 \mathrm{~cm}^{-1}$ with spectral resolution of 1 $\mathrm{cm}^{-1}$ and average of 32 scans. Raman spectra were recorded at room temperature with microtriple grating spectrometer Horiba Jobin Yvon model T64000. The spectra were excited by $514.5 \mathrm{~nm}$ line of the Coherent INNOVA-400 argon ion laser. Laser power at the sample was $7 \mathrm{~mW}$.

\section{Calculations}

The quantum chemical calculations were performed with the Gaussian 09 package program at DFT-B3LYP level of theory (Frisch et al., 2009). The standard 6-311++G(d,p) basis set was used to carry out the calculation of molecular geometries, force fields, vibrational frequencies, as well as IR intensities and Raman activities.

\section{RESULTS AND DISCUSSION}

The molecule of aspartic acid is composed of 16 atoms and it does not have any molecule symmetry.

It is well known from experimental research (Navarrete, Hernández and Ramírez, 1994) that aspartic acid (ASP) takes zwitterionic form. But DFT calculations of single free molecule fail to give zwitterionic form (Tobler et al., 2014).

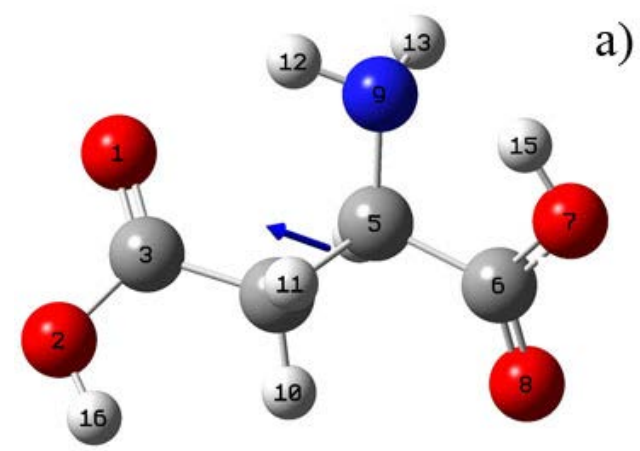

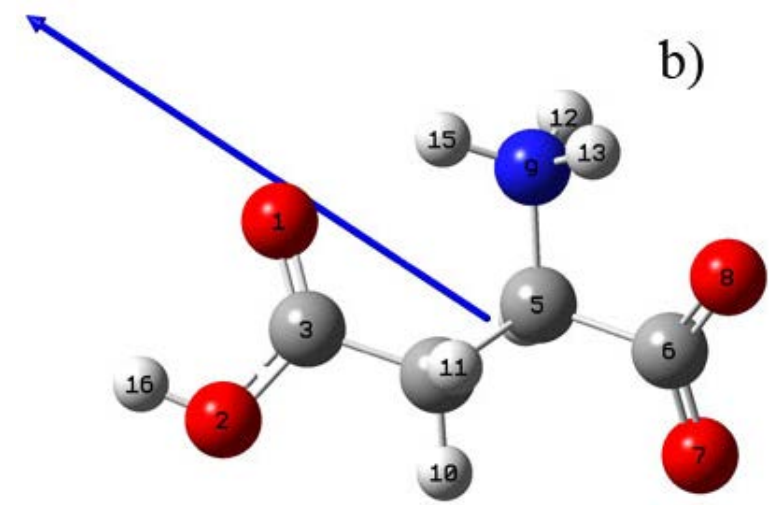

Figure 1. a) Single free molecule of aspartic acid.

b) Zwitterionic structure of aspartic acid. The blue arrow line represents dipole moments

For a single free molecule $(\varepsilon=1)$, the only way to obtain its zwitterionic structure is to place it in dielectric environment. Our first attempt was to calculate it in aqueous environment, by setting the relative dielectric constant to 82. Detailed inspection of relative dielectric constant set the low limit around $\varepsilon=3$ for stability of zwitterionic structure.

The dipole moments of these two forms significantly differ in magnitude but not in direction. Just for comparison, the dipole moment of single free molecule is 1.6 D and for zwitterionic conformation is around $7 \mathrm{D}$ for $\varepsilon=3$ (Fig. 1).

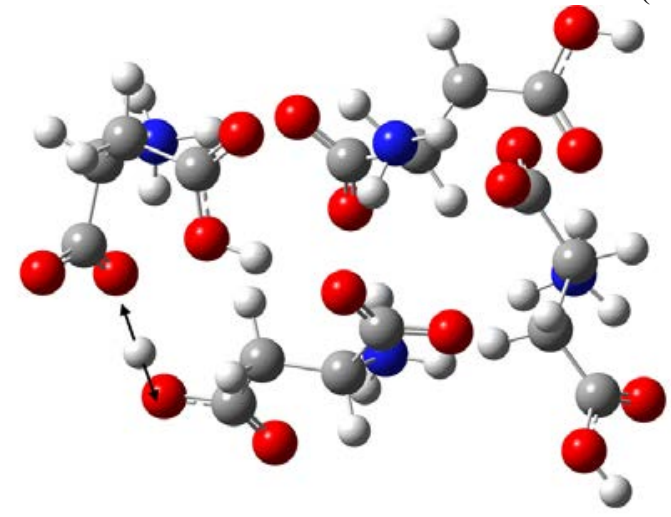

Figure 2. Optimized structure of four aspartic acid molecules in zwitterionic conformation. The arrows show proton movement in intermolecular hydrogen bonding corresponding to bands in the $2500-2700 \mathrm{~cm}^{-1}$ range

Further calculations show that even a small group of molecules creates a necessary dielectric environment which makes all molecules stable in zwitterionic form. In other words, the dielectric environment is self-induced with sufficient dielectric constant. In Figure 2 an optimized geometry for a group of four molecules is shown in zwitterionic form without any specified environment.

Stretching of $\mathrm{OH}$ and $\mathrm{NH}$ groups in our calculations of quadrimer structure have lowered significantly from the values calculated for one zwitterionic ASP molecule. For hydroxy groups surrounded with other molecules, the shifts are in the $600-1000 \mathrm{~cm}^{-1}$ frequency range. The most IR intensive amino groups stretching have lowered from approximately $3400 \mathrm{~cm}^{-1}$ to the 3000 and even to the $2700 \mathrm{~cm}^{-1}$. One part of the lowered hydrogen bonding vibrational modes falls in the region of $\mathrm{CH}$ and $\mathrm{CH}_{2}$ stretching. The other part of these modes is lowered even 
more, up to the $2500 \mathrm{~cm}^{-1}$. If the hydroxy or amino group is on the edge of the cluster, there is no shift, which can be explained by the lack of the influence of surrounding molecules.

Our biggest calculated cluster consists of four ASP molecules because of numerical limitations. In our powdered sample, we presume that clusters consist of larger number of ASP molecules. Because of that, number of "marginal" hydroxy and amino groups is small in comparison to the hydroxy and amino groups that are surrounded with other molecules. That is consistent with the experimental spectra of powdered samples, in which there are no $\mathrm{OH}$ and $\mathrm{NH}$ stretching bands at expected frequencies, around $3600 \mathrm{~cm}^{-1}$ and $3400 \mathrm{~cm}^{-1}$ respectively (Figure 3). But there exists a broad line around $3000 \mathrm{~cm}^{-1}$ consisting of $\mathrm{CH}$ stretching overlapping with lowered $\mathrm{OH}$ and NH stretching. Bands at 2510, 2661 and $2729 \mathrm{~cm}^{-1}$ (Figure 3) can be explained as $\mathrm{OH}$ stretching in intermolecular hydrogen bonding within the cluster (Stuart, 2004). Our calculations show these bands correspond to proton movement between $\mathrm{O}-\mathrm{O}$ and $\mathrm{O}-\mathrm{N}$ atoms (Figure 2).

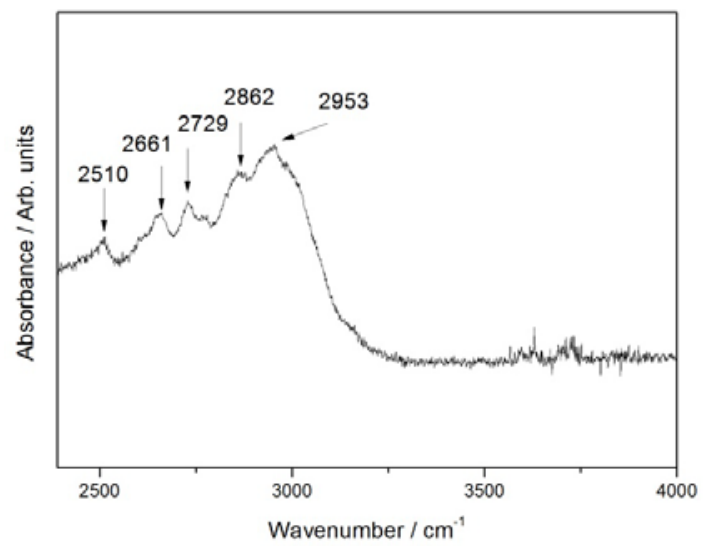

Figure 3. Infrared spectrum of aspartic acid in the $2400-4000 \mathrm{~cm}^{-1}$ region

Bands at 2510, 2661 and $2729 \mathrm{~cm}^{-1}$ are interpreted as belonging to proton movements between two oxygen atoms or between oxygen and nitrogen atoms. Higher bands belong to $\mathrm{CH}$ and lowered $\mathrm{OH}$ stretching.

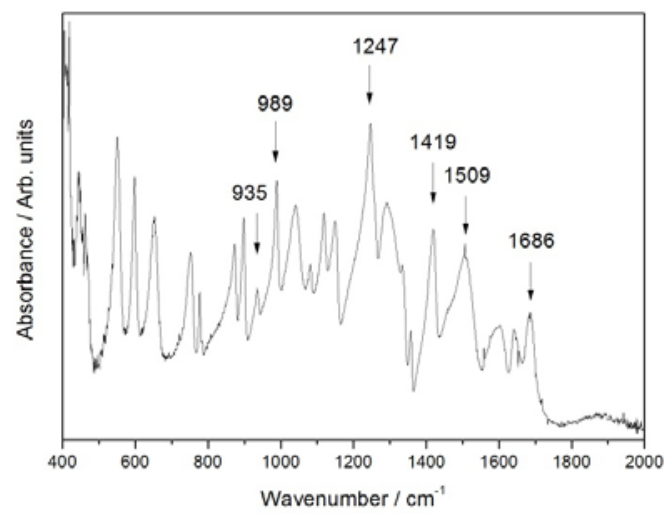

Figure 4. Infrared spectrum of aspartic acid in the $400-2000 \mathrm{~cm}^{-1}$ region

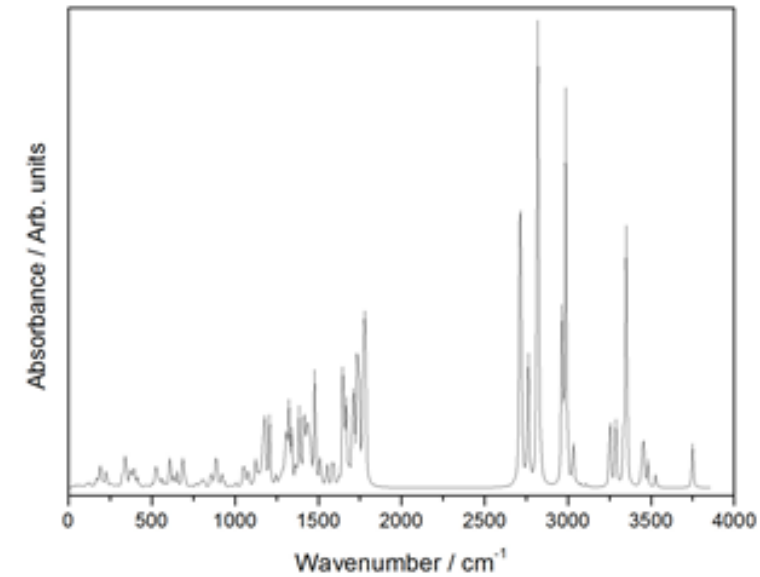

Figure 5. Calculated infrared spectrum of four members cluster presented in Fig. 2

The main characteristic of our observed infrared spectrum is a composition of broad vibrational bands (Figure 3 and 4). Calculated IR spectrum of aspartic acid cluster also shows grouping of bands (Figure 5). Same vibrations in different molecules of the sample have slightly different frequencies. That is consistent with broader bands observed in experimental FTIR spectra.

Infrared and Raman spectra presented at Figures 4, 6 and 7 show vibrational bands assigned to NH3+ group vibrations. Calculated and observed vibrational modes for zwitterionic form of aspartic acid molecule are presented in Table 1. Broad IR band at $1509 \mathrm{~cm}^{-1}$ belongs to NH3+ asymmetrical bending. In the frequency range from 989 to $1247 \mathrm{~cm}^{-1}$, we observe, both in IR and Raman spectra, NH3+ rocking combined with other modes. This is generally consistent with the results of past research although they have used different computational method (Navarrete, Hernández and Ramírez, 1994.)

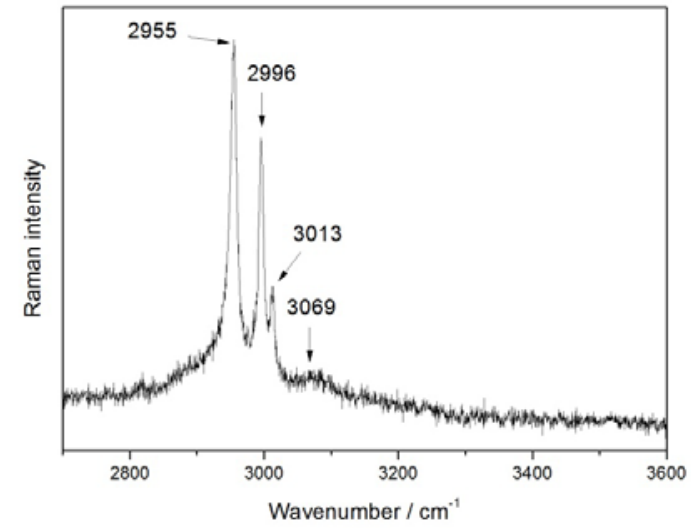

Figure 6. Raman spectrum of aspartic acid in $2700-3600 \mathrm{~cm}^{-1}$ region 


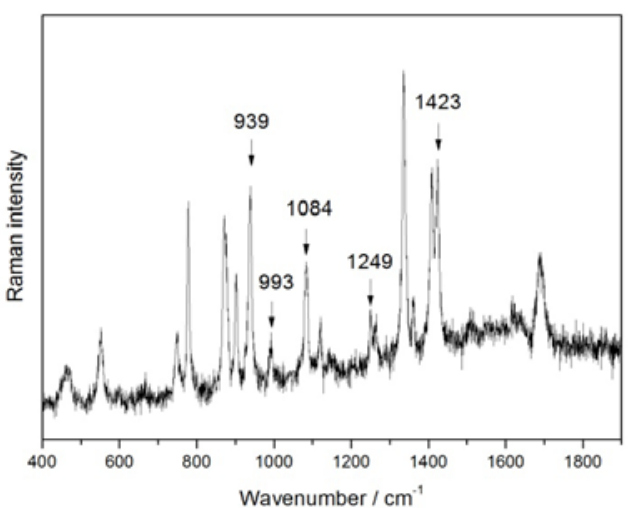

Figure 7. Raman spectrum of aspartic acid in $400-1900 \mathrm{~cm}^{-1}$ region

Table 1. Calculated and observed frequencies $\left(\mathrm{cm}^{-1}\right)$ for zwitterionic form of aspartic acid molecule

\begin{tabular}{|c|c|c|c|c|}
\hline & \multicolumn{2}{|c|}{ Observed $^{\mathrm{a}}$} & \multirow[b]{2}{*}{ Calculated $^{\mathrm{b}}$} & \multirow[b]{2}{*}{ Vibrational mode } \\
\hline & IR & Raman & & \\
\hline 1 & & & 3722 & $\mathrm{OH}$ str \\
\hline 2 & & & 3507 & NH str \\
\hline 3 & & & 3353 & $\mathrm{NH}_{3}$ asym str \\
\hline 4 & & $3069 \mathrm{w}$ & 3279 & $\mathrm{NH}_{3}$ sym str \\
\hline 5 & $3018 \mathrm{w}, \mathrm{sh}$ & $3013 \mathrm{~m}$ & 3136 & $\mathrm{CH}_{2}$ asym str \\
\hline 6 & $2985 \mathrm{w}, \mathrm{sh}$ & 2996 vs & 3127 & $\mathrm{CH}$ str \\
\hline 7 & 2953, s & 2955 vs & 3037 & $\mathrm{CH}_{2}$ sym str \\
\hline 8 & $1686 \mathrm{~s}$ & $1687 \mathrm{~s}$ & 1743 & $\mathrm{C}=\mathrm{O}$ str, $\mathrm{NH}_{3}$ asym bend \\
\hline 9 & $1641 \mathrm{~m}$, broad & $1640 \mathrm{w}$ & 1674 & $\mathrm{NH}_{3}$ asym bend, $\mathrm{COO}^{-}$asym str \\
\hline 10 & & $1618 \mathrm{w}$ & 1661 & $\mathrm{COO}^{-}$asym str, $\mathrm{NH}_{3}$ asym bend \\
\hline 11 & 1507 s, broad & $1508 \mathrm{w}$ & 1626 & $\mathrm{NH}_{3}{ }^{+}$asym bend \\
\hline 12 & $1459 \mathrm{w}, \mathrm{sh}$ & $1462 \mathrm{w}$ & 1460 & $\mathrm{CH}_{2}$ sciss \\
\hline 13 & $1419 \mathrm{~s}$ & $1423 \mathrm{~s}$ & 1434 & $\mathrm{NH}_{3}{ }^{+}$sym bend \\
\hline 14 & $1408 \mathrm{sh}$ & $1409 \mathrm{~s}$ & 1406 & $\mathrm{CO}$ str, $\mathrm{OH}$ bend, $\mathrm{CH}_{2}$ wag, $\mathrm{CC}$ str, $\mathrm{CH}$ bend \\
\hline 15 & $1358 \mathrm{~m}$ & $1362 \mathrm{~m}$ & 1396 & $\mathrm{CH}$ bend \\
\hline 16 & $1334 \mathrm{~m}$ & $1335 \mathrm{~s}$ & 1350 & CC str, $\mathrm{COO}^{-}$sym str, $\mathrm{NH}_{3}$ sym bend, $\mathrm{CH}$ bend \\
\hline 17 & 1291 broad & & 1330 & $\mathrm{CH}_{2}$ wagg, $\mathrm{OH}$ bend, $\mathrm{CH}$ bend \\
\hline 18 & $1258 \mathrm{sh}$ & $1263 \mathrm{w}$ & 1281 & $\mathrm{CH}_{2}$ twist, $\mathrm{OH}$ bend, $\mathrm{CH}$ band \\
\hline 19 & $1247 \mathrm{~s}$ & $1249 \mathrm{~m}$ & 1250 & $\mathrm{CH}_{2}$ twist, $\mathrm{CH}$ bend, $\mathrm{NH}_{3}$ rock, $\mathrm{COH}$ bend \\
\hline 20 & $1149 \mathrm{~m}$ & $1143 \mathrm{w}$ & 1183 & $\mathrm{OH}$ bend, $\mathrm{CH}$ bend, $\mathrm{NH}_{3}$ rock, $\mathrm{CO}$ str, $\mathrm{CH}_{2}$ twist \\
\hline 21 & $1118 \mathrm{~m}$ & $1121 \mathrm{~m}$ & 1142 & $\mathrm{CH}$ bend, $\mathrm{NH}_{3}$ rock, $\mathrm{CH}_{2}$ twist, $\mathrm{OH}$ bend \\
\hline 22 & $1081 \mathrm{w}$ & $1084 \mathrm{~m}$ & 1103 & $\mathrm{NH}_{3}$ rock, $\mathrm{CH}$ bend, $\mathrm{CH}_{2}$ twist \\
\hline 23 & $1042 \mathrm{~m}$ broad & & 1049 & CN str, CC str \\
\hline 24 & $989 \mathrm{~s}$ & $995 \mathrm{~m}$ & 964 & $\mathrm{CC}$ str, $\mathrm{NH}_{3}$ rock \\
\hline 25 & $935 \mathrm{w}$ & $939 \mathrm{~s}$ & 928 & CC str, CCC bend \\
\hline 26 & $897 \mathrm{~m}$ & $903 \mathrm{~m}$ & 870 & CC str, $\mathrm{COH}$ bend \\
\hline 27 & $872 \mathrm{~m}$ & $872 \mathrm{~s}$ & 843 & CN str, CC str \\
\hline 28 & $777 \mathrm{~m}$ & $778 \mathrm{~s}$ & 765 & OCO- out of plane bending \\
\hline 29 & $752 \mathrm{~m}$ & $752 \mathrm{~m}$ & 725 & OCOH out of plane bending, $\mathrm{COO}^{-}$in plane bend. \\
\hline 30 & $653 \mathrm{~m}$ & $658 \mathrm{vw}$ & 664 & OCOH out of plane bending \\
\hline 31 & $598 \mathrm{~s}$ & $600 \mathrm{vw}$ & 622 & OCOH out of plane bending \\
\hline 32 & $550 \mathrm{~s}$ & $552 \mathrm{~m}$ & 551 & OCOH out of plane bending \\
\hline
\end{tabular}


Table 2. The most relevant vibrational modes and frequencies $\left(\mathrm{cm}^{-1}\right)$ of group of four aspartic acid molecules

\begin{tabular}{|c|c|c|c|c|}
\hline \multicolumn{2}{|c|}{ Calculated } & \multicolumn{2}{c|}{ Observed } & \\
\hline ASP quadrimer & ASP zwitterionic & IR & Raman & OH stretching \\
\hline $\begin{array}{c}\text { 3751, 3749, 3351, } \\
\text { 2821 }\end{array}$ & 3722 & & & NH stretching \\
\hline $\begin{array}{c}\text { 3527, 3481, 3456, } \\
\text { 3447, } \\
\text { 3336, 3290, 3254, } \\
\begin{array}{c}\text { 3031, } \\
\text { 2988, 2762, } \\
2714\end{array}\end{array}$ & 3507, 3353, 3279 & & & \\
\hline $\begin{array}{c}1650,1623, \\
1590,1553\end{array}$ & 1626 & $1509 \mathrm{~s}$ & $1508 \mathrm{w}$ & $\mathrm{NH}_{3}{ }^{+}$asymmetric bending \\
\hline $\begin{array}{c}1512,1484, \\
1478,1443\end{array}$ & 1434 & $1419 \mathrm{~s}$ & $1423 \mathrm{~s}$ & $\mathrm{NH}_{3}{ }^{+}$symmetric bending \\
\hline $\begin{array}{c}1185,1176,1051, \\
893\end{array}$ & 1183 & $935 \mathrm{w}$ & $939 \mathrm{~s}$ & $\begin{array}{c}\mathrm{OH}_{\text {in-plane bending }} \\
\mathrm{OH}_{\text {out-of-plane bending }}\end{array}$ \\
\hline
\end{tabular}

The vibrational modes shown in Table 2 can explain broadening of observed infrared bands. As can be seen, the calculated frequencies of a four-member group can have a bandwidth of around $100 \mathrm{~cm}^{-1}$. The broadening is mostly emphasized for NH3+ asymmetric bending.

A strong Raman band at $939 \mathrm{~cm}^{-1}$ is empirically assigned to OH out-of-plane bending (Zhu et al., 2011, Navarrete, Hernández and Ramírez, 1994, Castro et al., 1995). The calculation performed on single zwitterionic molecule shows very weak presence of this mode which is significantly entangled with skeletal vibrations, but shows strong presence of $\mathrm{OH}$ in-plane mode at $1183 \mathrm{~cm}^{-1}$. However, the calculation performed on aspartic acid quadrimer shows both $\mathrm{OH}$ in-plane and $\mathrm{OH}$ out-of-plane bending as strong modes. The $\mathrm{OH}$ groups on cluster's border show in-plane bending at higher frequencies (1185 and $1176 \mathrm{~cm}^{-1}$ are very close to $1183 \mathrm{~cm}^{-1}$ belonging to single zwitterionic molecule) while the $\mathrm{OH}$ group in the cluster's interior clearly show out-of-plane bending at significantly lower frequencies which are in agreement with observed frequencies (see Table 2).

\section{CONCLUSION}

The main points of this work can be summarized as:

- The $\mathrm{OH}$ and $\mathrm{NH}$ stretching modes frequencies are significantly shifted to lower values within the powder of aspartic acid. Both experimental and calculated spectra prefer zwitterionic form of aspartic acid molecules.

- The DFT optimization of a single ASP zwitterionic molecule can be achieved only in dielectric environment with $\varepsilon r \geq 3$. The optimization of a group of aspartic acid molecules in zwitterionic form is possible due to the selfinduced dielectric environment.

- The grouping of molecules is responsible for broadening of vibrational bands in infrared spectrum. This is confirmed by DFT calculations.

- The complexity of intermolecular hydrogen bonding is the main cause for the broadening of spectral lines and their significant shifting to lower values.

\section{Author Contributions}

The manuscript was written through contributions of all authors. All authors have given approval to the final version of the manuscript. ¥These authors contributed equally.

$\ddagger$ Andrej Vidak, ¥Iva Movre Šapić, \$Vladimir Dananić.

\section{Acknowledgment}

We thank prof. Vesna Volovšek, $\mathrm{PhD}$ and Assist. prof. Vilko Mandic, PhD from Faculty of Chemical Engineering and Technology, University of Zagreb, for help in obtaining experimental data of Raman and IR spectroscopy. 


\section{REFERENCES}

Alam, M. J., \& Ahmad, S. (2012). Anharmonic vibrational studies of L-aspartic acid using HF and DFT calculations. Spectrochimica Acta Part A: Molecular and Biomolecular Spectroscopy, 96, 992-1004.

Alper, J. S., Dothe, H., \& Coker, D. F. (1991). Vibrational structure of the solvated glycine zwitterion. Chemical physics, 153(1-2), 51-62.

Castro, J. L., Montañez, M. A., Otero, J. C., \& Marcos, J. I. (1995). SERS and vibrational spectra of aspartic acid. Journal of molecular structure, 349, 113-116.

Derissen, J. L., Endeman, H. J., \& Peerdeman, A. F. (1968). The crystal and molecular structure of Laspartic acid. Acta Crystallographica Section B: Structural Crystallography and Crystal Chemistry, 24(10), 1349-1354.

Frisch, M. J. et al. Gaussian 09, Revision D.01 (Gaussian, Inc., Wallingford, Connecticut, 2009.

Freire, P. T., Barboza, F. M., Lima, J. A., Melo, F. E., \& Mendes Filho, J. (2017). Raman Spectroscopy of Amino Acid Crystals. In Raman Spectroscopy and Applications. IntechOpen.

Garrett, R. G., \& Grisham, C. M. (2010) Biochemistry (4.th ed.), Brooks/Cole, Boston.

Gontrani, L., Mennucci, B., \& Tomasi, J. (2000). Glycine and alanine: a theoretical study of solvent effects upon energetics and molecular response properties. Journal of Molecular Structure: Theochem, 500(1-3), 113-127.

Iijima, K., \& Beagley, B. (1991). An electron diffraction study of gaseous $\alpha$-alanine, $\mathrm{NH} 2 \mathrm{CHCH} 3 \mathrm{CO} 2 \mathrm{H}$. Journal of molecular structure, 248(1-2), 133-142.

Iijima, K., Tanaka, K., \& Onuma, S. (1991). Main conformer of gaseous glycine: molecular structure and rotational barrier from electron diffraction data and rotational constants. Journal of molecular structure, 246(3-4), 257-266.

Kumar, S. (2016). Vibrational study of aspartic acids. AKGEC Int. J. Technol, 7, 60-64.

Nagy, P. I., \& Noszál, B. (2000). Theoretical study of the tautomeric/conformational equilibrium of aspartic acid zwitterions in aqueous solution. The Journal of Physical Chemistry A, 104(29), 6834-6843.

Navarrete, J. L., Hernández, V., \& Ramirez, F. J. (1994). Ir and Raman spectra of $\mathrm{L}$ derivatives. Biopolymers: Original Research on Biomolecules, 34(8), 1065-1077.

Numata, Y., Otsuka, M., Yamagishi, K., \& Tanaka, H. (2017). Quantitative determination of glycine, alanine, aspartic acid, glutamic acid, phenylalanine, and tryptophan by Raman spectroscopy. Analytical Letters, 50(4), 651-662.

Patil, A., Bhide, S., Bookwala, M., Soneta, B., Shankar, V., Almotairy, A., \& Murthy, S. N. (2018). Stability of organoleptic agents in pharmaceuticals and cosmetics. AAPS PharmSciTech, 19(1), 36-47.

Paxton, A. T., \& Harper, J. B. (2004). On the solvation of L-aspartic acid. Molecular Physics, 102(9-10), 953958.

Silva, A. M., Costa, S. N., Sales, F. A. M., Freire, V. N., Bezerra, E. M., Santos, R. P., ... \& Caetano, E. W. S. (2015). Vibrational Spectroscopy and Phonon-Related Properties of the L-Aspartic Acid Anhydrous Monoclinic Crystal. The Journal of Physical Chemistry A,

119(49), 11791-11803.

Stuart, B. (2004): Infrared Spectroscopy: Fundamentals and Applications, John Wiley \& Sons.

Tobler, D. J., Blanco, J. R., Dideriksen, K., Sand, K. K., Bovet, N., Benning, L. G., \& Stipp, S. L. S. (2014). The effect of aspartic acid and glycine on amorphous calcium carbonate (ACC) structure, stability and crystallization. Procedia Earth and Planetary Science, 10, 143-148.

Zhu, G., Zhu, X., Fan, Q., \& Wan, X. (2011). Raman spectra of amino acids and their aqueous solutions. Spectrochimica Acta Part A: Molecular and Biomolecular Spectroscopy, 78(3), 1187-1195.

\section{Summary/Sažetak}

Cilj našeg istraživanja je detekcija zwitterionske strukture asparaginske kiseline i potvrđivanje eksperimentalnih spektara $\mathrm{s}$ kvantno kemijskim proračunima. Eksperimentalni IR i Raman spektri asparaginske kiseline u prahu ne pokazuju OH i NH vibracijske vrpce u očekivanom spektralnom području. Pretpostavljamo da je zwitterionska struktura asparaginske kiseline odgovorna za snižavanje frekvencija tih vibracija. Opsežna eksperimentalna i računalna istraživanja podupiru tu pretpostavku. Izračun DFT-a snažno upućuje na potrebu za dielektričnom okolinom kako bi se stabilizirala zwitterionska struktura jedne molekule. Mreža intermolekularnih vodikovih veza između molekula asparaginske kiseline osigurava ovo dielektrično okruženje. DFT kvantno-mehanički izračuni potkrjepljuju ovu pretpostavku optimiranjem četveročlane skupine molekula, što također daje objašnjenje širokih linija IR spektra. 